Citation: Taşova M. \& Civelek M. E. (2019), The Effect of Self-Direction Action on Identification With Supervisor and Affirmative Commitment, BMIJ, (2019), 7(4): $1740-1750$ doi: http://dx.doi.org/10.15295/bmij.v7i4.1161

\title{
THE EFFECT OF SELF-DIRECTION ACTION ON IDENTIFICATION WITH SUPERVISOR AND AFFIRMATIVE COMMITMENT
}

\author{
Murat TAŞOVA ${ }^{1}$ \\ Mustafa Emre CIVELEK ${ }^{2}$
}

\author{
Received Date (Başvuru Tarihi): 08/07/2019 \\ Accepted Date (Kabul Tarihi): 04/09/2019 \\ Published Date (Yayın Tarihi): 25/09/2019
}

\begin{abstract}
Identification with supervisor and affirmative commitment are some of the emotional behaviors of employees. Self-direction action value is one of the ten basic values of Schwartz value classification. Self-direction action is related to autonomy of thought and represents the cognitive behaviors of employees. This research aims to demystify the effect of self-direction action on identification with supervisor and affirmative commitment. The importance of this study is to reveal the mechanism behind the relationship between cognitive and emotional behaviors. The research hypotheses put forward a negative relation between self-direction action and identification with supervisor and affirmative commitment. The hypotheses have been supported based on the results of the analyses. Self-Direction Action (SDA) has a negative effect on Identification with Supervisor (IDS) and on Affirmative Commitment (AFC).
\end{abstract}

Keywords: Self-Direction Action, Identification with Supervisor, Affirmative Commitment

JEL Codes: M10, M14

\section{KENDINII YÖNETME DAVRANIŞININ YÖNETİCINIIN DEĞERLERININN ÖZDEŞLEŞTİRILMESİ VE DUYGUSAL BAĞLILIK ÜZERİNE ETKİSI}

\section{$\ddot{O} Z$}

Çalışanların yöneticinin değerlerini kabullenerek kendisi ile özdeşleştirmesi ve duygusal bağlllık, çalışanların duygusal davranışlarından bazılarıdır. Kendini yönetme davranışı, Schwartz tarafindan oluşturulan sınıflamada yer alan on değerden birini oluşturmaktadır. Kendini yönetme davranışı, bağımsız düşünce biçimi ile ilgilidir ve çalışanların bilişsel davranışlarını temsil eder. Bu çalışmanın amacı, kendini yönetme davranışının yöneticiye bă̆lllı̆̆ın bir boyutu olan yöneticinin değerlerinin özdeşleştirilmesi ve duygusal bă̆lllık üzerine etkisini açıklamaya yardımcı olmaktır. Bu çalışmanın önemi, bilişsel ve duygusal davranışlar arasındaki ilişkinin mekanizmasını açıklı̆̆a kavuşturmaktır. Araştırmada kendini yönetme davranışı ile yöneticinin değerlerinin özdeşleştirilmesi ve duygusal bağlllık arasında negatif yönlü bir ilişki olacağ düşünülmüş ve hipotezler bu şekilde ileri sürülmüşür. Analiz sonuçlarına göre, oluşturulan hipotezler desteklenmiştir. Kendini yönetme davranışı ile yöneticinin değerlerinin özdeşleştirilmesi ve duygusal bağlılık arasında negatif yönlü bir ilişki ortaya çıkmıştır.

Anahtar Kelimeler: Kendini Yönetme Davranışı, Yöneticinin Değerlerinin Özdeşleştirilmesi, Duygusal Bă̆lılık JEL Kodu: M10, $M 14$

1 Dr., İstanbul Ticaret Üniversitesi, mtasova@yahoo.com 2 Dr. Öğr. Üyesi, İstanbul Ticaret Üniversitesi, ecivelek@ticaret.edu.tr

https://orcid.org/0000-0002-7312-208X https://orcid.org/0000-0002-2847-5126 


\section{INTRODUCTION}

Today, recent developments in technologies change the organizations' structure, culture; all the relations from operations to human resources but these changes are not happening in organizations, they rather happen among people in society and in business life. People in business life are not willing to stay more or commit themselves to the organizations or display loyalty to their supervisors. Less commitment is not a problem that has to do with the young generation. Members of the $\mathrm{X}$ and $\mathrm{Y}$ generation have less commitment to the organizations matched against other generations (Gursoy et al, 2008, Petroulas et al, 2010). Personal values are one of the most important factors in human life shape human behavior and attitudes in life. Organizational commitment is an important factor for sustainable growth and continuation of business. For this reason, it is important to determine individuals' values and individuals who have more commitment to their organizations.

Influenced heavily by Rokeach (1973) and Kluckhohn (1951), Schwartz (1992) defined human values as agreeable, trans-situational tasks that vary in significance, used as guiding principles in the lives of human being. Moreover, he makes a distinugishment among these values according to the kind of motivational goal they convey and how they have impact on our attitudes and particularly our decision-making processes (Schwartz, 1992). In the last fifty years, organizational commitment has been one of the most researched and linked issues with other organizational behavior issues. When the literature on the concept of organizational commitment is examined, it is seen that the concept of commitment is a desirable value for employees to have a sense of commitment as well as for Protestant business ethics and to be connected to their own profession, company and work groups. Morrow and McElroy (1986) classified the concept of commitment, especially with a value-oriented approach to the commitment, as commitment to union, commitment to career, and commitment to organization (Morrow and McElroy, 1986). Meyer and Herscowitch (2001) added more to the above definitions and groups of commitment (goal commitment), commitment to organizational change and commitment to strategy (Meyer and Herscowitch, 2001). Especially in the studies conducted by the researchers in the Far East, they focused on the organization to work with the manager with a new approach and make such classification under the name of loyalty to the supervisor (Chen et al, 2002). This paper focus on understanding the relationship between the self-direction action, identification with supervisor, and affirmative commitment. The aim of the research questions of this article is to 
find out the role of the self-direction action on identification with supervisor and affirmative commitment.

\section{CONCEPTUAL BACKGROUND}

\subsection{Self-Direction Action (SDA)}

Values can be defined as concepts or beliefs which express desired behaviors or situations. They guide the evaluation or selection of our acts or behaviors. They have both priority and superiority feature in special cases. Schwartz Value System is a model that consists of four main dimensions which are self-transcendence, openness to change, conservation and self-enhancement. Self-direction value includes free thought and action such as choosing, creating as well as examining (Schwartz, 2012). Self-direction action value is one of the ten basic values of Schwartz value classification. The conceptual definition of selfdirection proposes two possible subtypes which are autonomy of thought and of action. (Schwartz, 2012) Self-direction-action can be defined as the freedom which allows one to determine his / her own actions. Autonomy of thought conveys the development of and using one's understanding and intellectual competence, while autonomy of action encompasses exercising one's capacity to achieve goals which are self-chosen (Schwartz, 2012).

\subsection{Identification to Supervisor (IDS)}

Measures of loyalty to supervisor are part of the organizational commitment. O'Reilly and Chatmann (1986) focused on employee's psychological attachment to organization. Becker (1996) and Gregersen (1993) explained psychological attachment with two dimensions which are identification with supervisor and internalization of supervisor's values (Chen et al, 2002). O'Reilly and Chatman (1986) explained that attachment based on identification is also related to extrarole behavior, tenure intentions, and turnover. Commitment based on internalization is related positively to performance, and it has more strong connection with performance than commitment based on identification.

\subsection{Affirmative Commitment (AFC)}

Affirmative commitment is the most emphasized approach in other definitions and models related to commitment in the literature. Affective or emotional attachment expresses the individual's adoption of the identity of the organization, identification and enjoyment of membership as a member of the organization (Allen and Mayer, 1990). As stated earlier in 
O'Reilly and Chatman's model, it refers to a situation in which the individual identifies and internalizes the values of the organization.

\section{CONCEPTUAL MODEL AND HYPOTHESES DEVELOPMENT}

The model of the research in Figure 1 is comprised of two hypotheses suggested to find out the direct effect of Self-Direction Action on Identification to with Supervisor and Affirmative Commitment.

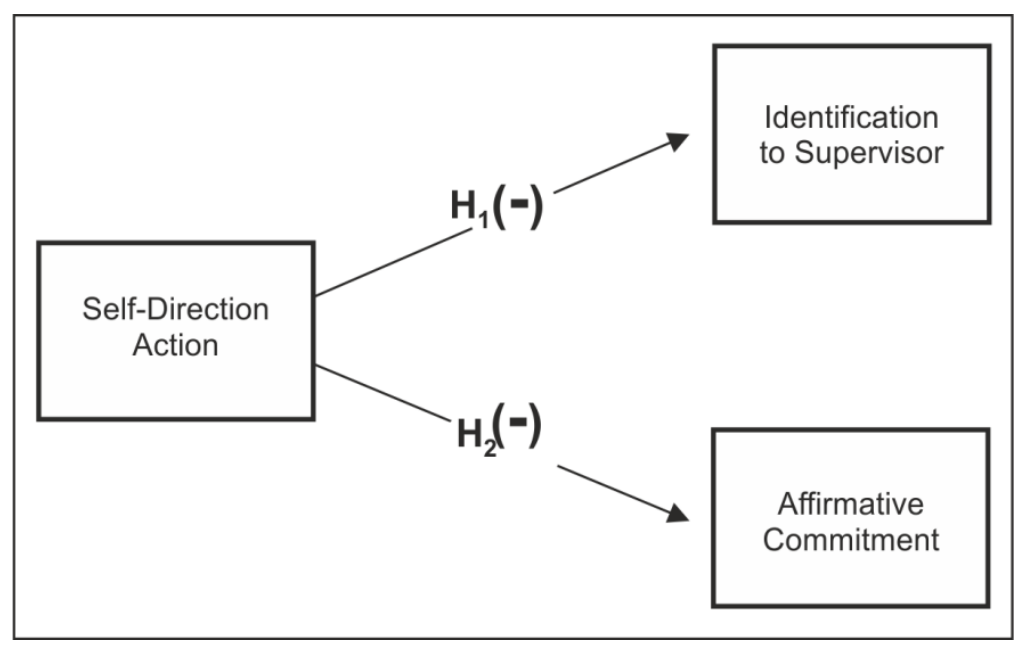

Figure 1. Research Model

\subsection{The Relationship between Self-Direction Action and Identification to Supervisor}

It is more likely for the supervisors that they create and promote performance norms more actively than workgroups and organizations. Hence, this study assessed commitment of the people or member of organization who have self-direction action values to organizations (affirmative commitment) and supervisors. Becker (1996) assessed commitment based on identification in his study and evaluated relations commitment based on identification with job performance. Thus, in this study, it was assessed and found out that Self-Direction Action (SDA) has a negative effect on Identification with Supervisor because of self-confidence, selfdecision-making skills and looking for new ideas.

Consequently, the following hypothesis was introduced:

$\mathbf{H}_{1}$ : Self-Direction Action (SDA) has a negative effect on Identification with Supervisor (IDS) 


\subsection{The Relationship between Self-Direction Action and Affirmative}

\section{Commitment}

Individuals who have the value of self-direction action are expected to show inadequate emotional attachment to the organization because of their own decision-making skills. Nonidentification with the current organization and not adopting or having an emotional bond with the organization means they use the organization for their own purposes. Schwartz explains this dimension as being interested in and curious about new ideas and making decisions freely by relying on their own decisions and plans (Schwartz, 2012).

It is assumed that individuals who have self-direction action will have higher rational decision-making skills than emotions.

Consequently, the following hypothesis was introduced:

$\mathbf{H}_{2}$ : Self-Direction Action (SDA) has a negative effect on Affirmative Commitment (AFC)

\section{RESEARCH METHOD}

For this research, quantitative research data were used. Questionnaire of the study comprises five-point Likert scale. The scales utilized in the survey were taken from current literature. Initially, to designate the validity, confirmatory factor analysis (CFA) was carried out and to designate the reliability, composite reliability and Cronbach $\alpha$ values were produced. Subsequently, the tests of the hypotheses that are suggested in the model of this research were carried out by means of covariance based structural Equation Modelling (CBSEM) method (Civelek, 2018). CB-SEM is the most preferred method in social sciences due to the fact that it allows the elimination of measurement errors (Civelek, 2018). The tests were performed with AMOS and SPSS software.

\subsection{Sampling and Measures}

The scales are taken from the extant literature. These scales were adopted to measure the constructs in the research model. Loyalty to supervisor scale was adopted from the study of Becker (1996) and Chen (2012). Organizational commitment scale was adopted based on the study of Allen and Mayer (1996). Finally, self-direction action scale was adopted alse from Schwartz (2012).

Having been distributed more than 500, 253 valid questionnaires were reached the respondents and this survey was performed in Turkey. 


\subsection{Reliability and Validity}

10 items remained after the elimination process. The remaining 10 items were entered into the confirmatory factor analysis (CFA) which is used to detect the validity of scales (Anderson \& Gerbing, 1988). In order to determine validity, fit indices should be examined. As a result of the analysis, the fit indices of the CFA model were found in the best level: $\chi 2 / \mathrm{DF}=1346, \mathrm{CFI}=0.990, \mathrm{IFI}=0.990, \mathrm{RMSEA}=0.037 . \mathrm{CMIN}$ means the Likelihood Ratio Chi-Square Test and indicates the consistence amont the acquired model and the initial model. CMIN/DF ratio was found to be below the adequate level of 3. Additionally, the result of the CMIN test is desired to be not significant. $\mathrm{P}$ value obtained CFA model is 0,091 . Other fit indices were found in the best degree (Bagozzi \& Yi, 1990).

As indicated in Table 1, factor loads were found to be more than 0.5 and statistically significant. Later, average variance extracted values were obtained. Results were found in the satisfactory degree (larger than 0.5) (Byrne, 2010). For designating the discriminant validity of scales, the square roots of AVE dgrees of each dimension were obtained. AVE results confirmed the convergent validity of the scales. The diagonals in Table 2 represent the square root of AVE values. Additionally, composite reliability and Cronbach $\alpha$ results are indicated in Table 2. These results were found in the satisfactory level (i.e. 0.7) (Fornell \& Larcker, 1981). Correlation values of the dimensions, AVE values, composite reliability and Cronbach $\alpha$ values of the dimensions are indicated in Table 2 .

Table 1. CFA Results

\begin{tabular}{llcc}
\hline Dimensions & Items & $\begin{array}{c}\text { Standardized } \\
\text { Factor Loads }\end{array}$ & $\begin{array}{c}\text { Unstandardized Factor } \\
\text { Loads }\end{array}$ \\
\hline \multirow{2}{*}{$\begin{array}{l}\text { Identification to Supervisor } \\
\text { (IDS) }\end{array}$} & Baid0134 & 0.624 & 1 \\
& Baid0336 & 0.831 & 1.356 \\
& Baid0235 & 0.845 & 1.348 \\
& Baid0437 & 0.901 & 1.356 \\
\hline \multirow{2}{*}{ Affirmative Commitment } & Baac0505 & 0.746 & 1 \\
(AFC) & Baac0808 & 0.812 & 1.101 \\
& Baac0606 & 0.848 & 1.161 \\
\hline \multirow{2}{*}{ Self-Direction Action (SDA) } & Kdsa0230 & 0.690 & 1.057 \\
& Kdsa0116 & 0.788 & 1.182 \\
\hline p<0.01 for all items & & &
\end{tabular}


Table 2. Correlations of the Constructs

\begin{tabular}{llll}
\hline Variables & 1 & 2 & 3 \\
\hline 1. Identification to Supervisor & $(0.807)$ & & \\
2. Affirmative Commitment & -0.013 & $(0.803)$ & \\
3. Self-Direction Action & $-0.145^{*}$ & $-0.285^{*}$ & $(0.720)$ \\
\hline Composite reliability & 0.880 & 0.892 & 0.693 \\
Average variance ext. & 0.651 & 0.645 & 0.518 \\
Cronbach $\alpha$ & 0.875 & 0.845 & 0.762 \\
\hline * $<0.05$ & & &
\end{tabular}

Note: Values in bracket represent the square root of AVEs.

\subsection{Analysis of the Hypotheses}

To proof the hypotheses, maximum likelihood estimation method was preferred. In CB-SEM, fit of the structural regression model was decided by means of the goodness of fit indicators. Comparative fit index (CFI) and the incremental fit index (IFI) are called as the relative goodness of fit indices (Akgün, Ince, Imamoğlu, Keskin, \& Kocoğlu, 2014). The most used indicators are the root mean square error of approximation (RMSEA) and $\chi^{2}$ value. These are the absolute goodness of fit indices. As depicted in Figure 2, goodness of fit indices determines that model fitted in satisfactorily. $\chi 2 / D F$ value is 1.324 and above threshold degrees (i.e. 3). Furthermore, the outcome of the test result of CMIN is desired to be not significant. $\mathrm{P}$ value obtained path model is 0,101 . CFI is 0.990 , IFI is 0.990 . RMSEA is 0.036. These values are adequate. As shown in Table $3, \mathrm{H}_{1}$ and $\mathrm{H}_{2}$ hypotheses are supported. 


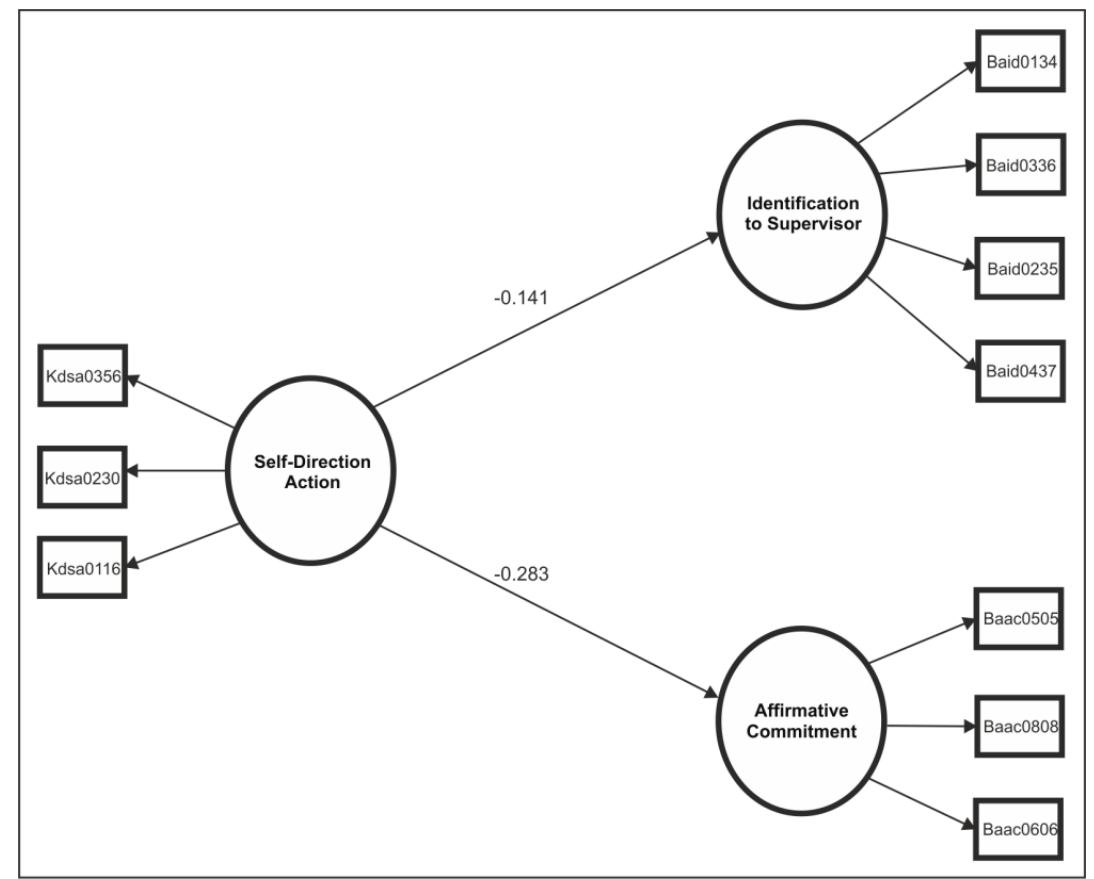

Figure 2. SEM Analysis

Note: $\chi 2 / \mathrm{DF}=1.324, \mathrm{CFI}=0.990, \mathrm{IFI}=0.990, \mathrm{RMSEA}=0.036$

Table 3. Coefficients of the Relationships

\begin{tabular}{lcc}
\hline Relationships & $\begin{array}{c}\text { Standardized } \\
\text { Coefficients }\end{array}$ & $\begin{array}{c}\text { Unstandardized } \\
\text { Coefficients }\end{array}$ \\
\hline Self-Direction Action $\rightarrow$ Identification to Supervisor & $-0.141^{*}$ & $-0.260^{*}$ \\
Self-Direction Action $\rightarrow$ Affirmative Commitment & $-0.283^{*}$ & $-0.631^{*}$ \\
\hline
\end{tabular}

$* \mathrm{p}<0.05$

\section{CONCLUSION}

\subsection{Managerial Implications}

This study has aimed to contribute to the literature by exploring the relationship between self-direction action on identification to supervisor and affirmative commitment. The research hypotheses propose a negative relationship between self-direction action and identification with supervisor and affirmative commitment. The results support the hypotheses; Self-Direction Action (SDA) has a negative effect on Identification with Supervisor (IDS) and on Affirmative Commitment (AFC). Findings are consistent with the literature. Self direction values which is the part of the openness to change values conflicts with goals of tradition values such a commitment to beliefs and norms (Ashkanasy et al, 2010). One significant result of this study has put forward that employees in self-direction 
action values have no loyalty to supervisor (identification with supervisor values) or commitment to the organizations (in affirmative commitment).

It is expected that this finding will encourage scholars and practitioners to adopt a more changed view towards employee commitment. Further commitment to supervisors was more strongly linked to performance than to commitment to organizations (Allen and Meyer, 1996). Yet, in the study of Chen (2012) there is no significant relation between the identification with supervisor and role performance (Chen at al, 2002). Moreover; commitment based on internalization of supervisory and organizational values was associated with performance too.

In the organizations of today, it is too hard to commit people who have self-direction action values to the organization and supervisors. Our results suggest that enhancing commitment via ensuring effective participation in decision making processes in the organizations, team building and participant organizational culture would affect the performance of people. It should also be noted that continuance commitment (rewards and side benefits) is still so important to ensure commitment in organizations. As De Castro (2016) stated in his study, more reward makes more commitment in today's organizations.

One of the implications based on the results of the study is that human resource professionals and scholars who deal with employee performance must concentrated on their efforts on commitment to supervisors rather than to organizations.

\subsection{Future Research Suggestions and Limitations}

For purposes intended to open a road for further research, it is of critical value to state some of the limitations related to this study and make suggestions for further research. It is believed that a future study based on the relationship between self-direction action on employee performance and continuance commitment will contribute to the literature by exploring the today's debates on commitment. 


\section{REFERENCES}

Akgün, A. e., Ince, H., Imamoğlu, S., Keskin, H., \& Kocoğlu, I. (2014). The mediator role of learning capability and business innovativeness between total quality management and financial performance. International Journal of Production Research, 52(3), 888-901.

Allen, Natalie J. and John P. Meyer. (1990). “The Measurement and Antecedents of Affective, Continuance and Normative Commitment To The Organization", Journal of Occupational Psychology, 63, 1-18

Allen, Natalie J. and John P. Meyer. (1996). "Affective, Continuance, and Normative Commitment to the Organization: An Examination of Construct Validity”, Journal Of Vocational Behavior 49, 252-276

Anderson, J., \& Gerbing, D. (1988). Structural Equation Modelling in Practice: A Review and Recommended Two-Step Approach. Psychological Bulletin.

Ashkanasy, N. M., Wilderom, C. P. \& Peterson, M. F. (2010). The handbook of organizational culture and climate Thousand Oaks, CA: SAGE Publications, Inc. doi: 10.4135/9781483307961

Bagozzi, R. P., \& Yi, Y. (1990). Assessing Method Variance in Multitrait-Multimethod Matrices: The Case of Self-Reported Affect and Perceptions at Work. Journal of Applied Psychology, 75(1), 547-560.

Becker, Thomas E. Robert S. Billings; Daniel M. Eveleth; Nicole L. Gilbert (1996). "Foci and Bases of Employee Commitment: Implications for Job Performance” The Academy of Management Journal, Vol. 39, No. 2., pp. 464-482.

Byrne, B. M. (2010). Structural Equation Modeling with AMOS. New York: Routledge Taylor \& Francis Group.

Chen, Zhen Xiong, Anne S. Tsui and Jiing-Lih Farh. (2002)."Loyalty to Supervisor vs. Organizational Commitment: Relationships to Employee Performance in China", Journal of Occupational and Organizational Psychology, 75, 339-354

Civelek, M. (2018). Comparison of Covariance-Based and Partial Least Square Structural Equation Modeling Methods under Non-Normal Distribution and Small Sample Size Limitations. Eurasian Econometrics, Statistics \& Empirical Economics Journal, 10, 39-50.

Civelek, M. (2018). Essentials of Structural Equation Modeling. Lincoln: University of Nebraska Lincoln-Zea Books.

De Castro, Marcela Lage Monteiro, Mário Teixeira Reis Neto, Cláudia Aparecida Avelar Ferreira, Jorge Filipe da Silva Gomes.(2016), " Values, motivation, commitment, performance and rewards: analysis model", Business Process Management Journal Vol. 22 No. 6, pp. 1139-1169

Fornell, C., \& Larcker, D. (1981). Evaluating Structural Equation Models with Unobservable Variables and Measurement Error. Journal of Marketing Research, 18(1), 39-50.

Gürsoy, Doğan, Thomas A. Maier and Christina G. Chi. (2008).“Generational Differences: An Examination Of Work Values And Generational Gaps İn The Hospitality Workforce”, International Journal of Hospitality Management 27, 2008, 448-458 
Meyer, John P., Lynne Herscowitch. (2001). "Commitment in the Workplace Towards a General Model", Human Resource Management Review 11, 299-326

Morrow, P.C. ve McElroy, J.C. (1986) "Research Notes on Assessing Measures of Work Commitment”, Journal of Vocational Behaviors, Vol.7,139-145

Petroulas, Emma, David Brown \& Heidi Sundin. (2010). "Generational Characteristics and Their Impact on Preference for Management Control Systems", Australian Accounting Review No. 54 Vol. 20 Issue 3, 221 240

O'Reilly, Charles III and Jennifer Chatman. (1986). "Organizational Commitment and Psychological Attachment: The Effects of Compliance, Identification, and Internalization on Prosocial Behavior", Journal of Applied Psychology Vol. 71, No. 3, 492-499

Schwartz, Shalom H.W. B. (1987). Toward A Universal Psychological Structure of Human Values. Journal of ftnonality and Social Psychology, Viol. 53, No. 3, 550-562.

Schwartz, S.H., (!992). "Universals In The Content And Structure Of Values: Theoritical Advances And Emperical Tests In 20 Countries", In Advances In Experimental Social Psychology, Academic Press, London, Volume 25, 1-65

Schwartz, Shalom \& Cieciuch, Jan \& Vecchione, Michele \& Davidov, Eldad \& Fischer, Ronald \& Beierlein, Constanze \& Ramos, Alice \& Verkasalo, Markku \& Lönnqvist, Jan-Erik \& Demirutku, Kursad \& dirilengumus, Ozlem \& Konty, Mark. (2012). Refining the theory of basic individual values. Journal of Personality and Social Psychology. 103. 663-88 